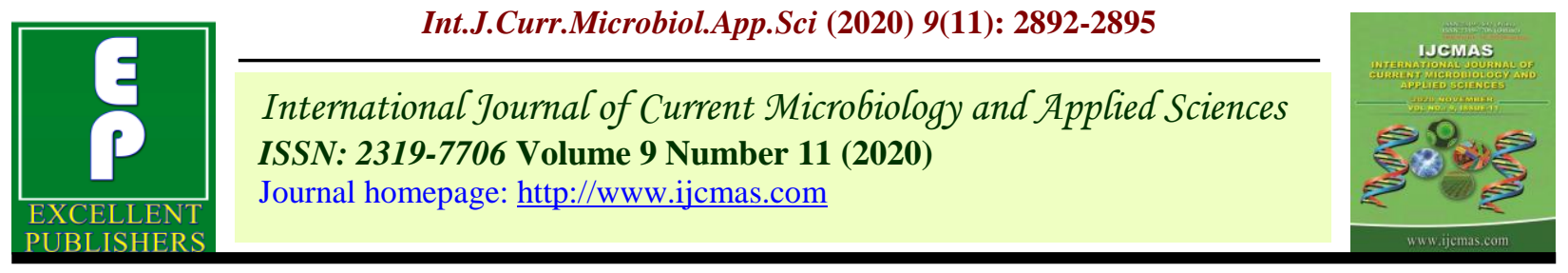

Original Research Article

https://doi.org/10.20546/ijcmas.2020.911.350

\title{
Genetic Variability for Yield Parameters in Local Maize (Zea mays L.) Genotypes of Nagaland
}

\author{
Malini B. Sharma* \\ Department of genetics and plant Breeding, SASRD, Nagaland University, Medziphema, India \\ *Corresponding author
}

\section{A B S T R A C T}

Keywords

Maize, Variability, GCV, PCV,

Heritability,

Genetic advance

\section{Article Info}

Accepted:

20 October 2020

Available Online:

10 November 2020
Twenty local maize germplasm collected from various parts of Nagaland along with a check variety was laid in randomized block design with two replications in the research farm of School of agricultural research and rural development, Nagaland University, Medziphema during kharif 2019 to determine the variability present amongst the genotypes. The results showed significant differences for all characters studied except for number of ears per plant. Many genotypes showed better performance than the check variety. PCV values were higher than the GCV values for all characters. High heritability with high genetic advance was observed for 100 seed weight, ear height and plant height.

\section{Introduction}

Maize (Zea mays L.) is an important crop cultivated in many countries under varied environmental conditions and can be grown throughout the year. It is most commonly known as "Corn" and is also dubbed as the 'Queen of cereals' and 'Miracle crop'. Morphologically maize exhibits greater diversity of phenotypes than any other grain crop (Kuleshov, 1933).

Maize is primarily cultivated for food, poultry feed, animal feed, industrial and also brewery purposes. In India, maize serves as one of the most important cereal crops after rice and wheat. Major maize producing states that contribute to most of the country's maize production are UP, Bihar, Rajasthan, Punjab, Madhya Pradesh, Himachal Pradesh, Jammu $\&$ Kashmir.

In Nagaland, maize is the second most important cereal after rice in terms of area about 68,960 ha and total production of 1,36,540 M.T and is grown in all districts of the state (Statistical Handbook of Nagaland, 2017). Maize in Nagaland is primarily cultivated under terrace and jhum areas. As maize is widely cultivated for self consumption purpose, livestock feed or for local market, fertilizers are seldom applied in 
the state. Sowing of maize in Nagaland proceed by the month of March in most areas, followed by the late sown types. Cultivation of maize in warmer region is done in late spring or early summer months. Different species of maize are found in Nagaland and each species exhibit different phenotypic traits or physical characteristics of its traits.

\section{Materials and Methods}

The work to access variability in 22 local genotypes (designated as G1,G2 ...to G22) collected from various regions of the state of Nagaland along with a check genotype RCM 75 was carried out in the institutional farm of School of Agricultural sciences and rural development, Medziphema in the kharif of 2019.

The 23 genotypes were placed in randomized block design with two replications and spacing of $60 \mathrm{~cm} \times 30 \mathrm{~cm}$ was maintained row to row and plant to plant respectively. Data on five randomly selected plants was recorded for 12 quantitative traits for recording yield parameters. The observations recorded are presented in Table 1.

\section{Results and Discussion}

Significant variability was observed for almost all characters under study except for number of ears per plant. G2 exhibited tallest plant height while G12 had the shortest stature. G7 was the earliest to mature while 100 seed weight was maximum in G14 followed by G2. Seed yield per plant ranged from $275.99 \mathrm{~g}$ to $61.85 \mathrm{~g}$ with genotype G13 showing the highest yield. Variability studies have been reported by various workers over the years including Hosamani et al., (2018), Khan et al., (2018) and Patil et al., (2018) who also reported substantial variability presence in genotypes of maize studied.
Genetic parameters like coefficient of variation, heritability and genetic advance is presented in table 2 . The GCV values were comparatively lower than the PCV values of the characters indicating environmental effect on performance. Reddy et al., (2012) also reported higher PVC than GCV for all characters under study revealing the role of experimental variance to total variance. GCV value was found highest for grain yield followed by 100 seed weight, plant height and ear height and lowest for ear width.

High heritability values for 100 seed weight, days to maturity, plant height, days to silking, days to tasselling and ear height was observed. The characters with high GCV and higher values of heritability indicated high potential for selection. Beulah et al., (2018) also reported high heritability for plant height, cob height and days to maturity.

Genetic advance was seen to be high in 100 seed weight, ear height and plant height indicating additive gene action. High heritability with high genetic advance for these traits are a good selection criteria in improving the yield. Sravanthi et al., (2017) also found similar result for ear height and yield per plant.

The performance of the local maize genotypes shows substantial variability present in it and many genotypes performed better than the check variety with respect to yield and yield attributing characters. High heritability values for 100 seed weight, days to maturity, plant height, days to silking, days to tasselling and ear height was observed. The characters with high GCV and higher values of heritability indicated high potential for selection. Beulah et al., (2018) also reported high heritability for plant height, cob height and days to maturity. 
Table.1 Mean performances of maize genotypes of Nagaland

\begin{tabular}{|c|c|c|c|c|c|c|c|c|c|c|c|c|}
\hline Genotypes & $\begin{array}{c}\text { Days to } \\
\text { tasseling }\end{array}$ & $\begin{array}{l}\text { Days } \\
\text { to } \\
\text { silking }\end{array}$ & $\begin{array}{c}\text { Plant } \\
\text { height } \\
(\mathrm{cm})\end{array}$ & $\begin{array}{c}\text { Ear } \\
\text { height } \\
(\mathrm{cm})\end{array}$ & $\begin{array}{c}\text { No. of } \\
\text { ears } \\
\text { per } \\
\text { plant }\end{array}$ & $\begin{array}{c}\text { Days to } \\
80 \% \\
\text { maturity }\end{array}$ & $\begin{array}{c}\text { Ear } \\
\text { length } \\
(\mathbf{c m})\end{array}$ & $\begin{array}{c}\text { Ear } \\
\text { width } \\
(\mathrm{cm})\end{array}$ & $\begin{array}{c}\text { No. of } \\
\text { kernel } \\
\text { rows }\end{array}$ & $\begin{array}{c}\text { No. of } \\
\text { kernels } \\
\text { per } \\
\text { row }\end{array}$ & $\begin{array}{c}100 \\
\text { seed } \\
\text { weight } \\
(\mathrm{g})\end{array}$ & $\begin{array}{c}\text { Grain } \\
\text { yield per } \\
\text { plant (g) }\end{array}$ \\
\hline $\mathbf{G}_{1}$ & 55.50 & 58.50 & 280.66 & 181.65 & 2.60 & 113.00 & 17.39 & 4.03 & 13.50 & 26.10 & 24.61 & 235.67 \\
\hline $\mathbf{G}_{2}$ & 53.50 & 57.00 & 302.49 & 196.85 & 2.20 & 109.90 & 19.74 & 3.97 & 10.30 & 31.00 & 32.04 & 216.75 \\
\hline $\mathbf{G}_{3}$ & 56.00 & 59.00 & 255.97 & 141.91 & 2.20 & 118.30 & 15.85 & 4.59 & 15.00 & 29.40 & 24.67 & 237.58 \\
\hline $\mathbf{G}_{4}$ & 55.00 & 58.00 & 158.03 & 104.95 & 2.00 & 124.20 & 16.99 & 4.28 & 11.20 & 22.60 & 12.97 & 62.39 \\
\hline $\mathbf{G}_{5}$ & 59.00 & 62.00 & 179.08 & 95.07 & 1.70 & 118.40 & 12.19 & 3.90 & 13.70 & 24.10 & 17.60 & 102.98 \\
\hline$G_{6}$ & 58.50 & 62.00 & 217.04 & 141.09 & 2.70 & 115.00 & 15.35 & 4.41 & 13.40 & 26.20 & 30.81 & 261.88 \\
\hline $\mathbf{G}_{7}$ & 44.50 & 48.00 & 188.54 & 106.21 & 2.00 & 108.50 & 18.98 & 4.07 & 11.60 & 30.10 & 26.14 & 180.28 \\
\hline $\mathbf{G}_{8}$ & 61.50 & 64.50 & 249.05 & 160.91 & 1.80 & 113.00 & 17.84 & 4.17 & 11.70 & 24.90 & 12.39 & 67.39 \\
\hline $\mathbf{G}_{9}$ & 54.00 & 57.00 & 215.82 & 126.36 & 1.80 & 119.90 & 13.46 & 3.66 & 15.30 & 28.90 & 12.77 & 94.53 \\
\hline $\mathbf{G}_{10}$ & 59.00 & 62.00 & 213.52 & 118.38 & 1.50 & 116.80 & 10.92 & 3.93 & 15.60 & 21.30 & 14.76 & 71.97 \\
\hline $\mathbf{G}_{11}$ & 60.50 & 63.50 & 277.65 & 163.95 & 2.90 & 128.10 & 12.53 & 3.45 & 14.40 & 24.00 & 11.94 & 111.20 \\
\hline $\mathbf{G}_{12}$ & 50.50 & 53.50 & 139.55 & 81.20 & 2.40 & 128.30 & 17.28 & 4.46 & 14.00 & 35.60 & 24.29 & 249.61 \\
\hline $\mathbf{G}_{13}$ & 53.00 & 56.00 & 216.63 & 114.29 & 2.50 & 116.00 & 17.45 & 4.23 & 14.50 & 30.00 & 27.71 & 275.99 \\
\hline $\mathbf{G}_{14}$ & 57.50 & 61.00 & 184.06 & 90.54 & 1.70 & 115.90 & 21.51 & 4.33 & 13.70 & 33.30 & 36.98 & 292.50 \\
\hline$G_{15}$ & 57.50 & 61.00 & 190.18 & 97.20 & 2.50 & 121.50 & 22.12 & 5.29 & 11.30 & 32.00 & 23.89 & 201.86 \\
\hline $\mathrm{G}_{16}$ & 63.50 & 67.00 & 210.81 & 106.70 & 1.90 & 128.30 & 15.69 & 4.28 & 14.90 & 20.90 & 21.40 & 124.97 \\
\hline $\mathbf{G}_{17}$ & 71.50 & 74.50 & 157.29 & 87.81 & 2.30 & 129.40 & 13.08 & 3.64 & 14.00 & 22.00 & 19.50 & 135.24 \\
\hline $\mathrm{G}_{18}$ & 55.50 & 59.00 & 228.73 & 112.25 & 3.10 & 130.50 & 19.44 & 4.15 & 13.80 & 33.10 & 18.81 & 264.80 \\
\hline $\mathrm{G}_{19}$ & 93.00 & 96.50 & 252.10 & 132.04 & 1.60 & 159.60 & 17.83 & 3.78 & 12.60 & 24.90 & 11.85 & 61.85 \\
\hline $\mathbf{G}_{20}$ & 83.50 & 87.00 & 289.79 & 171.05 & 2.20 & 154.40 & 19.49 & 3.49 & 15.30 & 23.50 & 25.55 & 192.37 \\
\hline $\mathbf{G}_{21}$ & 81.00 & 84.50 & 205.76 & 107.24 & 1.90 & 139.90 & 18.15 & 3.46 & 15.50 & 32.90 & 18.78 & 148.33 \\
\hline$G_{22}$ & 79.50 & 83.00 & 152.88 & 85.19 & 2.50 & 143.30 & 18.42 & 3.64 & 14.10 & 36.10 & 13.50 & 141.85 \\
\hline $\mathbf{G}_{23}$ & 54.50 & 58.00 & 182.38 & 93.11 & 2.00 & 113.20 & 11.26 & 3.65 & 11.40 & 22.10 & 16.11 & 77.71 \\
\hline Mean & 61.63 & 64.89 & 215.13 & 122.43 & 2.17 & 124.58 & 16.65 & 4.03 & 13.52 & 27.60 & 20.83 & 164.44 \\
\hline S.E & 1.16 & 1.18 & 5.75 & 6.22 & 0.37 & 1.37 & 1.12 & 0.25 & 0.51 & 2.40 & 0.93 & 36.45 \\
\hline C.D (5\%) & 3.41 & 3.47 & 16.88 & 18.26 & - & 4.03 & 3.30 & 0.74 & 1.51 & 7.043 & 2.73 & 106.92 \\
\hline C.V & 2.67 & 2.58 & 3.78 & 7.19 & 24.23 & 1.56 & 9.56 & 8.88 & 5.41 & 12.30 & 6.32 & 31.35 \\
\hline
\end{tabular}

Table. 2 Genetic parameters of 12 characters of local Maize genotypes of Nagaland

\begin{tabular}{|c|c|c|c|c|c|c|c|}
\hline \multirow[b]{2}{*}{ Character } & \multirow[t]{2}{*}{ Mean \pm S.E } & \multirow[t]{2}{*}{ Range } & \multicolumn{3}{|c|}{ Coefficient of variation } & \multirow{2}{*}{$\begin{array}{l}\text { Heritability } \\
\mathbf{h}^{2} \\
\text { (broad sense) }\end{array}$} & \multirow{2}{*}{$\begin{array}{l}\text { Genetic } \\
\text { advance } \\
\% \text { of mear }\end{array}$} \\
\hline & & & GCV & PCV & ECV & & \\
\hline Days to tasseling & $61.63 \pm 1.16$ & $93-44.5$ & 19.27 & 19.46 & 2.67 & 98.1 & 39.33 \\
\hline Days to silking & $64.89 \pm 1.18$ & $96.5-48$ & 18.43 & 18.61 & 2.58 & 98.1 & 37.60 \\
\hline Plant height (cm) & $215.13 \pm 5.75$ & $302.49-139.55$ & 21.26 & 21.59 & 3.78 & 96.9 & 43.12 \\
\hline Ear height (cm) & $122.43 \pm 6.22$ & $196.85-81.2$ & 26.62 & 27.57 & 7.19 & 93.2 & 52.94 \\
\hline No. of ears per plant & $2.17 \pm 0.37$ & $3.1-1.5$ & 9.46 & 26.01 & 24.23 & 13.2 & 7.10 \\
\hline Days to $80 \%$ maturity & $124.58 \pm 1.37$ & $159.6-108.5$ & 10.87 & 10.98 & 1.56 & 98.0 & 22.17 \\
\hline Ear length (cm) & $16.65 \pm 1.12$ & $22.12-10.92$ & 17.70 & 20.12 & 9.56 & 77.4 & 32.10 \\
\hline Ear width $(\mathrm{cm})$ & $4.03 \pm 0.25$ & $5.29-3.45$ & 8.73 & 12.45 & 8.88 & 49.2 & 12.61 \\
\hline No. of kernel rows & $13.51 \pm 0.51$ & $15.6-10.3$ & 10.98 & 12.24 & 5.41 & 80.5 & 20.30 \\
\hline No. of kernels per row & $27.60 \pm 2.40$ & $36.1-20.9$ & 15.05 & 19.44 & 12.30 & 60.0 & 24.01 \\
\hline 100 seed weight (g) & $20.83 \pm 0.93$ & $36.98-11.85$ & 34.04 & 34.62 & 6.32 & 96.7 & 68.94 \\
\hline Grain yield per plant (g) & $164.44 \pm 36.45$ & $275.99-61.85$ & 40.36 & 51.11 & 31.35 & 62.4 & 65.67 \\
\hline
\end{tabular}


Genetic advance was seen to be high in 100 seed weight, ear height and plant height indicating additive gene action. High heritability with high genetic advance for these traits are a good selection criteria in improving the yield. Sravanthi et al., (2017) also found similar result for ear height and yield per plant.

The performance of the local maize genotypes shows substantial variability present in it and many genotypes performed better than the check variety with respect to yield and yield attributing characters.

\section{References}

Beulah, G., Marker, S., Rajasekhar, D. 2018. Assessment of quantitative genetic variability and character association in Maize (Zea mays L.). Journal of Pharmacognosy and Phytochemistry, 7 (1): 2813-2816.

Hosamani, M., Kuchanur, P.H., Mahiboobsa, M., Nadakari, S.R and Honappa. 2018. Genetic variability for yield and yield attributing traits in maize (Zea mays L.). Journal of Pharmacognosy and Phytochemistry, 7 (3): 1964-1966.

Khan, M.H., Ahmad, M., Hussain, M., Hassan, M. and Ali, Q. 2018.
Heritability and traits association studies in maize F1 hybrids. International Journal of Biosciences, 12 (1) : 18-26.

Kuleshov, N.N. 1993. World's diversity of phenotypes of maize. Journal of Agronomy, 25: 688-700.

Patil, S.M., Chavan, L.N., Kauthale, V.K., Nalawade, A.D. 2018. AgroMorphological Characterization of Maize (Zea mays L.) Landraces from Tribal Block of Nandurbar District in Maharashtra (India). International Journal of Pure and Applied Bioscience, 6 (6) : 266-270.

Reddy, V.R., Jabee, F., Sudarshan, M.R. and Rao, A.S. 2013. Studies on Genetic Variability, Heritability, Correlation and Path Analysis in Maize (Zea mays L.) over Locations. International Journal of Applied Biology and Pharmaceutical Technology, 4 (1): 195-199.

Sravanti, K., Devi, I.S., Sudarshan, M.R. and Supriya, K. 2017. Evaluation of Maize Genotypes (Zea mays L.) for Variability, Heritability and Genetic Advance. International Journal of Current Microbiology and Applied Sciences, 6(10): 2227-2232.

\section{How to cite this article:}

Malini B. Sharma. 2020. Genetic Variability for Yield Parameters in Local Maize (Zea mays L.) Genotypes of Nagaland. Int.J.Curr.Microbiol.App.Sci. 9(11): 2892-2895. doi: https://doi.org/10.20546/ijcmas.2020.911.350 